УДК: 338.012:94:63:316.334.55(477)'’20",

DOI: 10.26697/ijes.2019.4.34

\section{Формування аграрних відносин в українському селі на початку XXI століття}

Професор Каденюк О. С. ${ }^{1}$

${ }^{1}$ Подільський державний аграрно-технічний університет, Україна

\section{Резюме}

\section{Вступ:}

Зміни в аграрних відносинах в українському селі на початку XXI століття визначалися реформуванням аграрної сфери виробництва, що призвело до появи перших фермерських господарств, які виникали стихійно, в умовах затяжного протистояння 3 антиринковими силами. Спираючись лише на власні можливості, а після прийняття у 1991 р. Верховною Радою Закону "Про селянське (фермерське) господарство" й на символічну допомогу держави, вони з часом зайняли своє місце в аграрній економіці.

\section{Методи: \\ Аналіз інтересів основних груп сільських виробників у перше десятиліття незалежності України свідчить, що серед членів колективних підприємств готовність до заснування самостійних фермерських господарств була обмеженою.}

\section{Результати:}

В новій економічній парадигмі національної продовольчої безпеки України в XXI ст., підготовленій Інститутом аграрної економіки УААН, наприклад, фермерські господарства розглядаються як “економічна база середнього класу”. На перший погляд позиція науковців заслуговує схвалення. Та їхні подальші міркування розчаровують: фермерству, по суті, відводиться роль підсобних селянських господарств забезпечувати продовольством внутрішній ринок. Регіональні ж продовольчі потреби, виробництво сировини для переробних галузей, формування державних фондів продовольства, ресурсів для зовнішньої торгівлі повинен взяти на себе корпоративний сектор. Очевидною $\epsilon$ підміна понять, ігнорування основних виробничих рис фермерства як загальноцивілізаційного явища. Поперше, за таких умов фермерство ніколи не стане середнім класом, по-друге, за своїми параметрами фермерські господарства не зможуть прилучитися до сучасних європейських підприємств такого типу. Переведення власності у статус приватноорендної у багатьох випадках означає існування в суспільстві прихованих форм домінування. Таким прихованим власникам невигідно ні самим інтенсифікувати підконтрольні їм господарства ні давати можливість робити це іншим, оскільки право власності юридично не закріплене і передача ініціативи означатиме втрату контролю. Так, більшість керівників цих підприємств не була зацікавлена в реструктуризації галузі. Частина керівників виявилася нездатною до виконання завдань у нових умовах господарювання. Збільшився тиск на них і з боку конкурентів.У суспільній свідомості та й подеколи і в науковцями проти фермерства виставляється чимало аргументів, серед яких чи не найголовнішим називається потреба нового способу господарювання у великих фінансових ресурсах. За розрахунками фахівців, на створення одного сучасного фермерського господарства (будівництво житла, господарських приміщень, придбання необхідної техніки, реманенту тощо) потрібно витратити понад мільйон гривень. Прибічники так званої елітарної моделі створення фермерських господарств пропонують зосереджувати засоби, що будуть виділені 3 цією метою державою, у підпорядкованому урядові монопольному земельному банку і через нього переводити їх у комерційні банки, що займатимуться облаштуванням фермерських садиб i передаватимуть готові ферми вибраним господарям у лізинг, тобто в оренду. Переважна більшість науковців і самих фермерів вважає такий шлях неефективним і з соціального, i в політичного погляду: по-перше, він не даватиме змоги їм самим, за допомогою власних сил $\mathrm{i}$ здібностей, розв'язувати господарські проблеми, по-друге, “прив'язуватиме” до хазяїна-благодійника довічним відробітком. Крім того, цей шлях неефективний і 3 економічного погляду - у зв'язку 3 тривалим терміном окупності великої суми одноразових капіталовкладень.

\section{Висновки:}

Селянин-фермер є головною ланкою в модернізації сільського господарства, розбудови демократичної держави, а також змін в системі суспільних відносин. Прискорюючи процес формування різноманітних форм власності, господарювання й управління, фермери створюють умови для реальної конкуренції між виробниками сільськогосподарської продукції, що $є$ важливою умовою розвитку на основі скасування мораторію на продаж землі.

\section{Інформація про автора: \\ Каденюк Олександр Степанович - доктор історичних наук, професор кафедри теоретико- правових i соціально-гуманітарних дисциплін, Подільський державний аграрно-технічний університет, Кам'янець-Подільський, Україна. \\ Наукові інтереси: всесвітня історія, соціально- економічні та політичні відносини, аграрна історія; https://orcid.org/0000-0002-2173-6055.}

\section{Автор-Кореспондент:}

Каденюк Олександр Степанович

Email Автора-Кореспондента: akadenyuk@gmail.com 